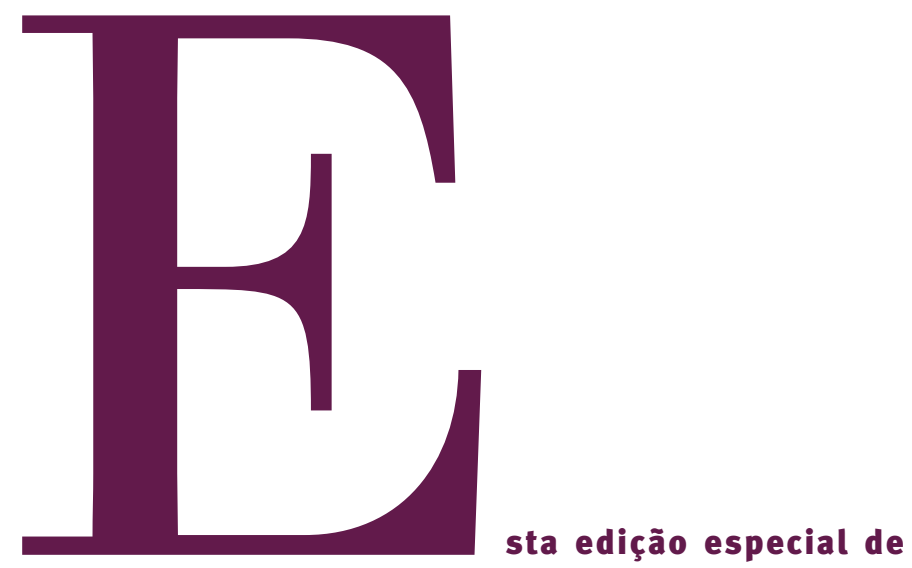

Cadernos Cenpec trata de um tema instigante, envolvente e relevante: a juventude dos grandes centros urbanos.

Consideramos importante que experiências significativas no campo da formação de jovens possam ser compartilhadas e socializadas. Aqueles que criam e implementam projetos no campo da educação brasileira têm o compromisso social e político de disseminar, espalhar e colocar à disposição, os saberes que produzem.

Não obstante o reiterado discurso da falta e da carência, que muitas vezes imobiliza a ação, porque se encerra na denúncia, apresentamos aqui uma iniciativa que aposta na potência, na possibilidade real de despertar o desejo e a vontade de futuro dos jovens moradores de regiões de grande risco social. Lugares que escancaram sua precariedade local, sua vulnerabilidade social, seus riscos ambientais.

Depois de muitas experiências em projetos sobre a juventude, o Cenpec, em parceria com a Fundação Itaú Social, inaugurou em 2004 o programa Jovens Urbanos, que privilegia uma forte articulação com agências governamentais (nos âmbitos municipal e estadual), centros tecnológicos e ONGs que atuam com jovens nas periferias das cidades.

Inovador na oferta de experimentações vinculadas ao mundo da tecnologia, aos desejos dos jovens e às demandas das cidades, o programa estimula a circulação e intervenção na cidade e modifica a vida dos jovens e de

\section{Como multiplicar boas experiências de jovens urbanos}

sua comunidade. Experiências com aquecedores solares, intervenção e melhoria de espaços coletivos, tramas culturais as mais diversas exigiram dos jovens a problematização e a busca de soluções para questões que nunca tinham tido a oportunidade de resolver. Encará-las e enfrentar os desafios impostos pela realidade ampliou sua inventividade a um nível sem precedentes.

Queremos multiplicar com nossos leitores as opções metodológicas, estratégias processuais e tecnológicas adotadas na ação com a juventude. Mas também apresentamos nosso mergulho no conhecimento mais reflexivo sobre o universo juvenil que nos levou a procurar entender a complexidade e velocidade de sua vida em mutação e as novas formas de sociabilidade nos circuitos onde transitam.

Construímos com eles cartografias reais e simbólicas do possível que revelam as condições nas quais as juventudes das cidades se movem e desenvolvem suas trajetórias. Na periferia das duas maiores cidades do Brasil, Rio de Janeiro e São Paulo, pudemos nos aproximar dos jovens e estimulá-los a apropriarem-se de modo novo das tecnologias da cidade, criar e recriar imagens, comunicarem-se com mais competência e alegria.

Esperamos que todos possam navegar conosco nestes canais abertos pelos jovens e ampliar espaços de ação com e para eles. Apostamos que eles podem chegar onde querem, se sociedade organizada e governos estiverem juntos nesta caminhada. 